\title{
PRODUCTION AND PROPERTIES OF THE CELLULASE-FREE XYLANASE FROM THERMOMYCES LANUGINOSUS IOC-4145
}

\author{
Mônica Caramez Triches Damaso ${ }^{1 *}$; Carolina M.M. Carvalho Andrade² Nei Pereira Jr. $^{1}$ \\ ${ }^{1}$ Departamento de Engenharia Bioquímica, Escola de Química da Universidade Federal do Rio de Janeiro, Rio de Janeiro, RJ, \\ Brasil. ${ }^{2}$ Rio Technology Center - White Martins Gases Industriais LTDA, Rio de Janeiro, RJ, Brasil.
}

Submitted: May 08, 2002; Returned to authors for corrections: August 01, 2002; Approved: December 05, 2002

\begin{abstract}
In recent years, xylanases have expanded their use in many processing industries, such as pulp and paper, food and textile. Thermomyces lanuginosus IOC-4145 was able to produce a very high level of cellulase-free xylanase in shaken cultures using corncob as substrate $(500 \mathrm{U} / \mathrm{mL})$. An optimization of the medium composition in submerged fermentation was carried out aiming at a low cost medium composition for enzyme production. Statistical experiment design was employed for this purpose, pointing out corncob as the most important parameter, which affects enzyme production. Additionally, the influence of several chemicals on xylanase activity was investigated in the crude extract. A slight stimulation of the enzyme (5-15\%) was achieved with $\mathrm{NaCl}$ and urea, both at 3 and $5 \mathrm{mM}$ of concentration. On the other hand, dithiothreitol and $\beta$-mercaptoethanol at a molarity of $5 \mathrm{mM}$ have caused a strong stimulation of the enzyme (40-53\%). The crude xylanase displayed appreciable thermostability, retaining almost $50 \%$ of activity during 24 hours of incubation at $50^{\circ} \mathrm{C}$; about $50 \%$ of activity was present at $60^{\circ} \mathrm{C}$ even after 4 hours of incubation. The enzyme also exhibited good storage stability at $-20^{\circ} \mathrm{C}$ without any stabilizing agent.
\end{abstract}

Key words: Xylanases, Thermomyces lanuginosus, corncob, submerged fermentation, medium optimization

\section{INTRODUCTION}

In the last decades, it has been emphasized that the use of xylanolytic enzymes could greatly improve the overall economics of processing lignocellulosic materials for the generation of liquid fuels and chemicals (3). Besides, cellulasefree xylanases have received great attention in the development of environmental friendly technologies in the paper and pulp industry $(2,9,16)$. Basically, the following benefits of the usage of xylanases in this industrial sector have been demonstrated: (i) reduction of chlorine-based chemicals and hydrogen peroxide, (ii) increase in the tear and burst strengths of the paper produced, and (iii) reduction in the chemical oxygen demand in the effluent discharge lines (2).

Purkarthofer et al. (21) were the first to report that the strain DSM5826 of Thermomyces lanuginosus was able to secrete xylanase during submerged cultivation in a complex medium. Accordingly, we have demonstrated that the strain IOC4145 of T. lanuginosus isolated from Brazilian soil was able to produce a high amount of cellulase-free xylanase (8). Generally, the carbon source has been estimated as the major cost factor in enzyme production. A reduction in the production costs can be achieved by the usage of inexpensive waste materials, such as corncob and sugar cane bagasse that are often reliable and abundant.

The aim of this work was to optimize the production of xylanase by Thermomyces lanuginosus IOC-4145 in shaken flasks using corncob as raw material. The optimization of medium composition was investigated using an experimental design. We focused our attention on developing a low-cost medium that would allow enhanced product recovery, as well as high enzyme productivity. Furthermore, the action of several

\footnotetext{
* Corresponding author. Mailing address: Departamento de Engenharia Bioquímica, Escola de Química da Universidade Federal do Rio de Janeiro. Caixa
} Postal 68542. 21949-900, Rio de Janeiro, RJ, Brasil. Tel.: (+5521) 2562-7646. Fax: (+5521) 2562-7567. E-mail: triches@eq.ufrj.br 
chemicals on enzyme activity, as well as the properties of the xylanase that are important for future applications were also studied.

\section{MATERIALS AND METHODS}

\section{Materials}

Chemicals. All chemicals were of analytical grade and obtained from Sigma unless otherwise stated. Agar-agar and meat extract were purchased from Merck.

\section{Organism and growth conditions}

The strain of Thermomyces lanuginosus used in this study was isolated from soil at the IBILCE/UNESP/SP, Brazil, and identified by Fundação Instituto Oswaldo Cruz, RJ, Brazil under the code IOC-4145. This strain was maintained on slants of oats agar: oats, $50.0 \mathrm{~g} / \mathrm{L}$ and agar, $30.0 \mathrm{~g} / \mathrm{L}$ at $4^{\circ} \mathrm{C}$. The composition of the production medium (PMKC) was as follows (in $\mathrm{g} / \mathrm{L}$ ): peptone, 10.0; meat extract, $10.0 ; \mathrm{NaCl}, 10.0 ; \mathrm{KH}_{2} \mathrm{PO}_{4}, 1.0$ and corncob at different concentrations.

\section{Spores and mycelia suspensions}

Spores suspensions were prepared by adding $3 \mathrm{~mL}$ of $0.1 \%$ Tween 80 to slant cultures and scrapping off the surface with a sterilized wire loop. These spores were counted in a Neubauer's chamber, and a standardized amount $\left(10^{6}\right.$ spores $\left./ \mathrm{mL}\right)$ was inoculated in the growth broth with the same composition as the PMKC broth, except for the carbon source, which was glucose. The experiments were carried out inoculating the PMKC broth with a mycelium suspension, germinated previously for 20 hours.

\section{Xylanase production in submerged fermentation}

Ten percent $(\mathrm{v} / \mathrm{v})$ mycelium suspension was used to inoculate conical flasks $(500 \mathrm{~mL}$ ) containing $3 \mathrm{~g}$ of corncob in $100 \mathrm{~mL}$ of PMKC medium. After inoculation, the flasks were incubated at $45^{\circ} \mathrm{C}$ in a rotatory shaker at $150 \mathrm{rpm}$. At each sampling time, the culture medium was vacuum filtered using Whatman $\mathrm{n}^{\circ} 4$ filter paper (fast-flow rate), and the filtrate was used for further enzymatic assays. During the cultivation, two flasks or more were sampled daily.

\section{Enzyme assays}

Xylanase was assayed by the optimized method described by Damaso et al. (8), using birchwood xylan as substrate. The solution of xylan and the enzyme at appropriate dilution were incubated at $75^{\circ} \mathrm{C}$ for 3 minutes and the reducing sugars were determined by the dinitrosalicylic acid procedure (18), with xylose as standard. The carboxymethylcellulolytic activity was assayed as stated by Damaso et al. (8). The released xylose or glucose was measured spectrophotometrically at $540 \mathrm{~nm}$. One unit $(\mathrm{U})$ of enzyme activity was defined as $1 \mu \mathrm{mol}$ of reducing sugar released per minute under the described assay conditions. Protein concentration was measured by the Lowry method (17) using bovine serum albumin (BSA) as standard.

All experiments were performed in duplicates and the analytical measurements at least in triplicates. Excel program was used to check the statistical confiability of the experimental data.

\section{Experimental design}

Four factors were studied for xylanase production: peptone, meat extract, corncob and $\mathrm{NaCl}$ concentrations. A $2^{4-1}$ Fractional Factorial Design (FFD), with two concentrations of each factor (Table 1), was effective in searching towards optimum domain. The xylanase production for each duplicate of shaken-flask run was determined after a growth period of 72 hours.

\section{Effect of ions and chemical reagents on the xylanase activity}

The effect of metal ions and other reagents on xylanase activity was determined using the crude enzyme. The enzyme activity was measured in the presence of salts and chemical reagents at concentrations of 3 and $5 \mathrm{mM}$.

Table 1. Assigned concentrations (in $\mathrm{g} / \mathrm{L}$ ) of variables of different levels of the $2^{4-1}$ fractional factorial design.

\begin{tabular}{lrr}
\hline \multicolumn{1}{c}{ Factor } & \multicolumn{2}{c}{ Level } \\
\cline { 2 - 3 } & -1 & +1 \\
\hline Peptone & 2 & 10 \\
Meat extract & 2 & 10 \\
NaCl & 2 & 10 \\
Corncob & 10 & 30 \\
\hline
\end{tabular}

\section{Xylanase stability}

The effect of temperature on the enzyme activity was determined after incubation of the crude extract at $50-90^{\circ} \mathrm{C}$ for different intervals of time. The residual activity was measured as previously described.

The stability of enzyme at storage was monitored during 6 months at $-20^{\circ} \mathrm{C}$, using one-month intervals. The residual activity was measured as stated above.

\section{RESULTS AND DISCUSSION}

\section{Kinetic of xylanases production in submerged fermentation}

The kinetic profile of the enzymatic production by $T$. lanuginosus IOC-4145 in liquid medium using 3\% (w/v) corncob as substrate was obtained after cultivation under agitation, at $45^{\circ} \mathrm{C}$ during 144 hours. The maximum peaks of xylanase production and specific activity occurred after 96 hours of cultivation (Fig. 1), resulting in values of $516 \mathrm{U} / \mathrm{mL}$ and $85 \mathrm{U} /$ $\mathrm{mg}$, respectively. It is worth to note that most of the protein 
produced is related to the xylanase secreted by the fungus. Moreover, no cellulase activity was detected in the crude extract.

High activities were obtained using corncob, denoting that this agroindustrial residue is a good substrate for xylanase production by $T$. lanuginosus IOC-4145. When compared with other data reported in the literature employing the same or different lignocellulosic materials and other microorganisms $(10,14)$, T. lanuginosus IOC-4145 showed to be a promising fungus for xylanase production, even when compared with other strains of T. lanuginosus cultivated under similar conditions, as strains: RT9 (13), DSM 5826 (21), ATCC22083, ATCC58160 and ATCC34626 (23) which produced 425, 1600, 455, 377 and $1170 \mathrm{U} / \mathrm{mL}$, respectively.

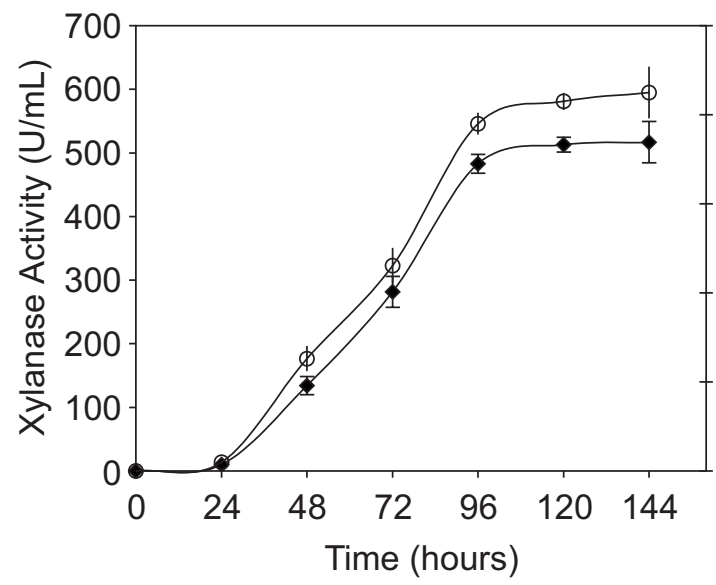

100
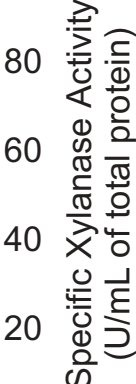

0

Figure 1. Kinetic profile of the xylanase production (- by T. lanuginosus IOC-4145 and its specific activity (-O-), using corncob $3 \%$ as substrate on submerged fermentation.

\section{Optimization of medium constituents}

Different statistical designs have been successfully employed for xylanase production on submerged fermentation $(12,13,21)$. Statistically designed experiments are very effective because the affecting parameters can be evaluated collectively, even with a limited number of experiments.
Experiments using $2^{4-1}$ Fractional Factorial Design (FFD) (19) were carried out with two values of each factor, as for attaining a low cost medium for xylanase production. We have found that the concentrations of carbon and nitrogen sources, as well as concentration of $\mathrm{NaCl}$ exert a high influence on xylanase production (Fig. 2). The maximum ( $248 \mathrm{U} / \mathrm{mL}$ ) and minimum (30 $\mathrm{U} / \mathrm{mL}$ ) xylanase activities were obtained in media M8 and M4, respectively (Table 2).

The Pareto chart was used to compare the amount of xylanase produced in all media, throughout the software STATISTICA $^{\mathrm{TM} \cdot 99}$ for windows version 5.5 (Fig. 2). The chart shows the values of " $t$ student" test for each component of the PMKC medium, and the spliced line indicates the minimal magnitude of statistically significant effects to a confidence level of $95 \%$.

Since corncob contains a very small amount of nitrogen $(0.66 \%)$, we can consider that peptone and meat extract were the only nitrogen sources used in the media (7). The Pareto chart clearly shows that these components do not have any significant effect on xylanase production, whilst $\mathrm{NaCl}$ presents a moderate effect. As far as the positive effect of this salt on xylanase production is concerned, the results displayed in Table

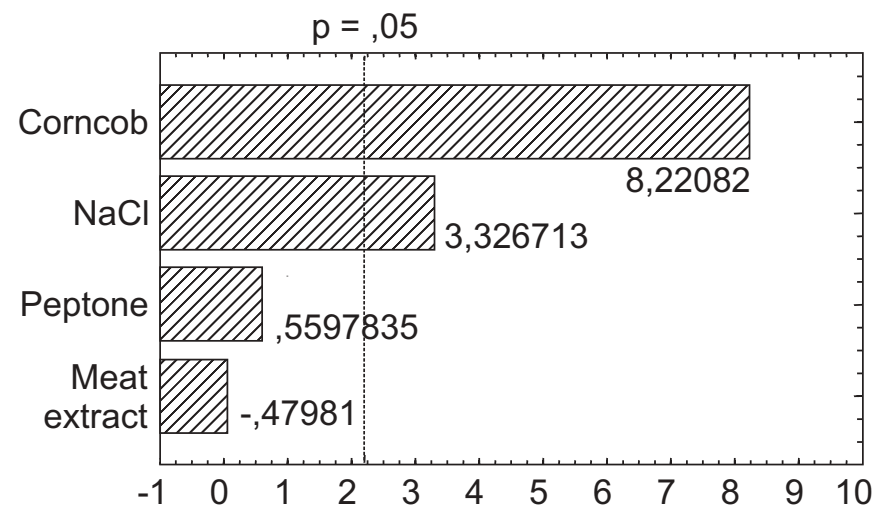

Figure 2. Pareto chart: the effect of components of medium production on xylanase synthesis from T. lanuginosus IOC4145.

Table 2. Effect of medium composition on the production of xylanases by T. lanuginosus IOC-4145 in shaken flasks.

\begin{tabular}{ccccccccc}
\hline Component $(\mathrm{g} / \mathrm{l})$ and results & M1 & M2 & M3 & M4 & M5 & M6 & M7 & M8 \\
\hline Peptone & 2 & 10 & 2 & 10 & 2 & 10 & 2 & 10 \\
Meat extract & 2 & 2 & 10 & 10 & 2 & 2 & 10 & 10 \\
NaCl & 2 & 2 & 2 & 2 & 10 & 10 & 10 & 10 \\
Corncob & 10 & 30 & 30 & 10 & 30 & 10 & 10 & 30 \\
Xylanase activity $(\mathrm{U} / \mathrm{mL})$ & $60 \pm 15$ & $202 \pm 7$ & $183 \pm 14$ & $30 \pm 4$ & $202 \pm 39$ & $116 \pm$ & $116 \pm 32$ & $248 \pm$ \\
Estimation FOB Price* (US $\$ / \mathrm{L}$ of medium) & 0.93 & 2.03 & 3.17 & 4.27 & 1.33 & 2.43 & 3.57 & 4.67 \\
\hline
\end{tabular}

${ }^{1}$ Corncob price was considered negligible. 
2 also corroborate the observation of the Pareto chart. The media containing the lowest $\mathrm{NaCl}$ concentration (M1 and M4) resulted in the lowest xylanase production. On the contrary, the ones possessing the highest $\mathrm{NaCl}$ concentration (M6 and M7) led to higher values of enzyme activity.

On the other hand, corncob has shown to be the most important factor that affects the enzyme production. Considering that the market of corn-based products is intensive worldwide and that a high amount of xylan is found in corncob, the utilization of this lignocellulosic residue is a very good choice for xylanase production. There is no production cost attached to it, although costs for collection and transportation of this residue to a centralized processing location can be high.

While for other microorganisms, the main impact in the medium price is due to the nitrogen source $(12,13), T$. lanuginosus showed not to be strongly dependent on this factor. As shown in Table 2, the M5 medium is the most promising, considering both the amount of xylanase obtained and the price of the enzyme production medium.

\section{Substrate specificity of xylanase}

The specificity of different xylan sources for xylanase produced by $T$. lanuginosus IOC-4145 was investigated. The highest activity was observed when oatspelt xylan was employed as substrate, although a great amount of released xylose from other xylan sources was also obtained (Table 3 ).

There is a great heterogeneity in the composition and structure of xylans from various sources. From this heterogeneity it can be expected that, depending on the structural features of the xylan, different combinations of enzymes may be required for maximum hydrolysis. While oatspelt xylan (Sigma) has lower amounts of arabinose, and thus, a lower degree of branching, birchwood xylan contains only minor amounts of arabinose, but large amounts of glucopyranosyl uronic acid. The presence of large amounts of substituents may hinder the formation of the enzymesubstrate complex and, consequently, reduce the enzymatic hydrolysis (15).

Table 3. Substrate specificity of xylanase of T. lanuginosus IOC-4145.

\begin{tabular}{cc}
\hline Kinds of xylan & Relative Activity (\%) \\
\hline Birchwood & $84 \pm 4$ \\
Beechwood & $77 \pm 6$ \\
Oatspelt & $100 \pm 5$ \\
\hline
\end{tabular}

Xylanase activity was measured by mixing a volume of enzyme (final concentration 5.44U) with a suspension of xylan $1 \%(\mathrm{w} / \mathrm{v})$ in $0.12 \mathrm{M}$ universal buffer, $\mathrm{pH} 6.0$, at $75^{\circ} \mathrm{C}$. The reducing sugars formed were measured, as xylose equivalents, by DNS method; The activity with oatspelt xylan was set as $100 \%$.

\section{Factors influencing xylanase activity}

The influence of different metal ions and other agents on xylanase activity is summarized in Table 4 . The effects varied according to the chemicals and to their concentration. Among the chemicals, $5 \mathrm{mM}$ as well as $\mathrm{Ba}^{2+}, \mathrm{Ca}^{2+}, \mathrm{Zn}^{2+}(5 \mathrm{mM}) \mathrm{SDS}$ caused a slight inhibition on the enzyme activity. Yet, the ions $\mathrm{Mg}^{2+}$ and $\mathrm{Fe}^{3+}$, at same concentration, led to an inhibition of approximately $25 \%$. On the other hand, $\mathrm{NaCl}$ and urea, both at concentrations of 3 and $5 \mathrm{mM}$ resulted in a slight stimulation on the enzyme activity. The explanation for these antagonic effects lies in the alteration of the enzyme conformation. As widely reported in the literature $(1,4,5,11)$ enzymes can be modulated by interaction of cations with amino acid residues involved in their active sites. Such interactions can either increase (positive modulation) or diminish (negative modulation) the enzyme catalytic activity.

Nonetheless, Numao et al. (20) studying the human pancreatic a-amylase (HPA), found out that some members of the amylase family require chloride for full catalytic activity. This characteristic is related to the existence of conserved chloride ion binding site located in domain $A$, which is an $\alpha / \beta$ barrel that contains the active site. Thus, not only cations but also anions can alter enzyme activity.

The protein disulfide reducing reagents, $\beta$-mercaptoethanol and dithiothreitol, caused a high stimulation of the xylanase activity, mainly at a concentration of $5 \mathrm{mM}$ (40-55\%). Such thiol compounds prevent oxidation of sulphydryl groups (4), that is why they are commonly added during enzyme purification (26). The stimulation of xylanase activity by such disulfide reducing agents indicates that cysteine residues should be a part of

Table 4. The effect of several chemicals on xylanase activity.

\begin{tabular}{crr}
\hline \multirow{2}{*}{ Chemical } & \multicolumn{2}{c}{ Relative Activity $(\%)^{*}$} \\
\cline { 2 - 3 } & \multicolumn{1}{c}{$3 \mathrm{mM}$} & \multicolumn{1}{c}{$5 \mathrm{mM}$} \\
\hline $\mathrm{NaCl}$ & $110 \pm 13$ & $113 \pm 3$ \\
$\mathrm{KCl}$ & $113 \pm 2$ & $96 \pm 5$ \\
$\mathrm{BaCl}_{2}$ & $98 \pm 6$ & $88 \pm 3$ \\
$\mathrm{CaCl}_{2}$ & $95 \pm 5$ & $89 \pm 4$ \\
$\mathrm{MgCl}_{2}$ & $106 \pm 4$ & $74 \pm 8$ \\
$\mathrm{FeCl}_{3}$ & $96 \pm 1$ & $78 \pm 2$ \\
$\mathrm{ZnCl}_{2}$ & $95 \pm 15$ & $90 \pm 3$ \\
Urea & $102 \pm 7$ & $113 \pm 5$ \\
$\mathrm{SDS}$ & $101 \pm 3$ & $93 \pm 2$ \\
Isopropanol & $95 \pm 4$ & $92 \pm 4$ \\
Ethanol & $100 \pm 1$ & $99 \pm 5$ \\
Triton X & $95 \pm 4$ & $91 \pm 3$ \\
-mercaptoethanol & $129 \pm 3$ & $153 \pm 3$ \\
Dithiothreitol & $113 \pm 11$ & $140 \pm 3$ \\
\hline
\end{tabular}

* The activity is expressed as a percentage of the activity level in the absence of chemicals (control). 
catalytic site in the enzyme structure, then the reduced form of these residues probably causes changes in the protein conformation resulting in an increased enzyme activity (1). Similar effects were described for xylanases from Bacillus sp. strain SPS-0 (1), Bacillus amyloliquefaciens (4), and also Thermomyces lanuginosus DSM 5826 (5) in the presence of those compounds.

\section{Xylanase stability}

The effect of temperature and $\mathrm{pH}$ on xylanolitic activity was previously studied (8). Xylanase activity was found over a wide range of temperatures, as well as $\mathrm{pH}$ values with the optimum at $75^{\circ} \mathrm{C}$ and 6,0 , respectively.

The investigation of the thermal stability of xylanase revealed that the enzyme was stable at $50^{\circ} \mathrm{C}$, showing a half-life of 24 hours. While at $60^{\circ} \mathrm{C}$ the enzyme retained $50 \%$ of the initial activity, after 4 hours of incubation at $70^{\circ} \mathrm{C}$ more than $80 \%$ of activity was lost after 1 hour (Fig. 3).

Storage of the crude culture containing xylanase at $-20^{\circ} \mathrm{C}$ resulted in a small loss (15 to 20\%) of the initial activity at the first 30 days, maintaining stable thereafter for 5 months. Storage stability is a key quality parameter for enzyme-based bleaching processes. Sufficient bleaching performance must be maintained from the time of the enzyme production until it is actually used. During this period, the product is stored and shipped under all kinds of conditions. Enzymes are the least stable ingredients in bleaching formulations, yet the most important in bleaching performance.

The stability of xylanase might be due to the protection caused by any compatible solute, such as the polymeric

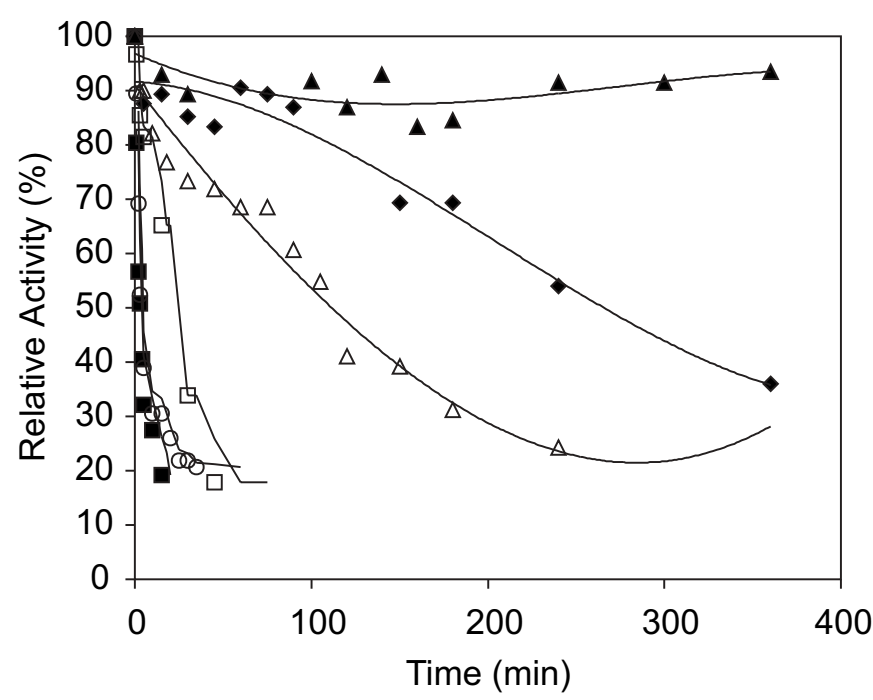

Figure 3. Thermostability of xylanase from $T$. lanuginosus IOC$4145.50^{\circ} \mathrm{C}(-\boldsymbol{\Delta}-) ; 60^{\circ} \mathrm{C}(-\backslash-) ; 65^{\circ} \mathrm{C}(-\triangle-) ; 70^{\circ} \mathrm{C}$ $(-\square-) ; 80^{\circ} \mathrm{C}(-\mathrm{O}-) ; 90^{\circ} \mathrm{C}(-\mathbf{\square})$. substrate xylan and/or xyloolygosaccharides resulting from the hydrolysis, which could exert a protective effect on the enzyme. These protection effects related to di- and trisaccharides and also polymeric ficoll on the restriction enzyme PstI were described by Colaço et al. (6). Sola-Penna and Meyer-Fernandes (24) suggested that the effect observed for trehalose as stabilizer of dehydrogenase is due to its larger hydrated volume.

Moreover, Vogt et al. (25) examined theoretically sixteen families of proteins with different thermal stability. In over $80 \%$ of the families, a correlation between thermostability and the number of hydrogen bonds was found. An increase in the fractional polar surface, resulted in additional hydrogen bonding. This provides the most general explanation for thermal stability in proteins. The number of ion pairs was also found to increase with thermal stability of two-thirds of the families investigated.

Kumar et al. (16) also studied 18 families of thermophilic and mesophilic proteins, whose structural factors could be responsible for thermostability. They observed that both thermophilic and mesophilic proteins have similar hydrophobicities, oligomeric states and hydrogen bonds. On the other hand, salt bridge numbers are higher in most thermophilic proteins. This fact can be explained since salt bridges and their networks rigidify protein structures. A higher concentration of salt bridges, particularly networks, "stitches" the structure of a protein, making it more resistant to local deformation/melting or unfolding at high temperatures (16).

The positive effect of $\mathrm{NaCl}$ and the existence of xylooligosacharides resulting from the xylanase action may contribute for the appreciable enzyme stability.

\section{ACKNOWLEDGMENTS}

This work was supported by grants from FAPERJ, CNPq, WUS (Proj.andra.255) and FINEP/PRONEX (014/98).

\section{RESUMO}

\section{Produção e propriedades de xilanase livre de celulase de Thermomyces lanuginosus IOC-4145}

Nos últimos anos tem crescido o uso de xilanases em muitas indústrias, tais como polpa e papel, alimentos e têxtil. Thermomyces lanuginosus IOC-4145 foi capaz de produzir um alto nível de xilanase livre de celulase em culturas agitadas usando sabugo de milho como substrato $(500 \mathrm{U} / \mathrm{mL})$. Procedeuse, inicialmente, à otimização da composição do meio de produção em fermentação submersa, com o intuito de alcançar uma composição de meio de produção de baixo custo para produção da enzima. Para este propósito, utilizou-se planejamento estatístico de experimentos. O sabugo de milho revelou-se como a mais importante variável que afeta a produção enzimática. Adicionalmente, a influência de vários reagentes na 
atividade xilanásica foi investigada no extrato bruto. Um pequeno estímulo na atividade enzimática $(5-15 \%)$ foi observado para $\mathrm{NaCl}$ e uréia, ambos nas concentrações de 3 e $5 \mathrm{mM}$. Por outro lado, ditiotreitol e $\beta$-mercaptoetanol $5 \mathrm{mM}$ causaram um grande estímulo na atividade xilanásica (40-53\%). A xilanase produzida apresentou apreciável termoestabilidade, retendo quase $50 \%$ da atividade inicial durante 24 horas de incubação a $50^{\circ} \mathrm{C}$ e, aproximadamente, $50 \%$ da atividade foram mantidos a $60^{\circ} \mathrm{C}$, mesmo após 4 horas de incubação. A enzima também exibiu boa estabilidade à estocagem a $-20^{\circ} \mathrm{C}$ na ausência de qualquer agente estabilizante.

Palavras-chave: Xilanases, Thermomyces lanuginosus, sabugo de milho, fermentação submersa, otimização de meio

\section{REFERENCES}

1. Bataillon, M.; Cardinali, A.P.N.; Castillon, N.; Duchiron, F. Purification and characterization of a moderately thermostable xylanase from Bacillus sp. Strain SPS-0. Enz. Microb. Technol., 26: 187-192, 2000.

2. Beg, Q.K.; Bhushan, B.; Kapoor, M.; Hoondal, G.S. Enhanced production of a thermostable xylanase from Streptomyces sp. QG11-3 and its application in biobleaching of eucalyptus Krakt pulp. Enz. Microb. Technol., 27: 459-466, 2000.

3. Biely, P. Microbial xylanotic systems. Trends Biotechnol., 3(11): 286-290, 1985.

4. Breccia, J.D.; Sineriz, F.; Baigori, M.D. Castro, G.R.; Hatti-Kaul, R. Purification and characterization of a thermostable xylanase from Bacillus amyloliquefaciens. Enz. Microb. Technol., 22: 4249, 1998.

5. Cesar, T.; Mrsa, V. Purification and properties of the xylanase produced by Thermomyces lanuginosus. Enz. Microb. Technol., 19: 289-296, 1996.

6. Colaço, C.; Sen, S.S.; Thangavelu, M.; Pinder, S.; Roser B. Extraordinary stability of enzymes dried in trehalose: simplified molecular biology. Bio/Technology, 10: 1007-1011, 1992.

7. Damaso, M.C.T. Produção de endoxilanases termoestáveis por Thermomyces lanuginosus IOC-4145 em meio semi-sólido. Rio de Janeiro, 1999, 123p. (MSc. Escola de Química. UFRJ).

8. Damaso, M.C.T.; Andrade, C.M.M.C.; Pereira Jr., N. The use of corncob for endoxylanase production by thermophilic fungus Thermomyces lanuginosus IOC 4145. Appl. Biochem. Biotechnol., 84-86: 821-834, 2000.

9. Dhillon, A.; Gupta, J.K.; Jauhari, B.M.; Khanna, S. A cellulase-poor, thermostable, alkalitolerant xylanase produced by Bacillus circulans $\mathrm{AB} 16$ grown on rice straw and its application in biobleaching of eucalyptus pulp. Bioresource Technol., 73: 273-277, 2000.
10. Gaspar, A.; Cosson, T.; Roques, C.; Thonart, Ph. Study on the Production of a Xylanolitic Complex from Penicillium canescens 10-10c. Appl. Biochem. Biotechnol., 6: 45-58, 1997.

11. Ghanem, N.B.; Yusef, H.H.; Mahrouse, H.K. Production of Aspergillus terreus xylanase in solid-state cultures: application of the Plackett-Burman experimental design to evaluate nutritional requirements. Bioresource Technol., 73: 113-121, 2000.

12. Gomes, J.; Gomes, I.; Kreiner, W.; Esterbauer, H.; Sinner, M.; Steiner, W. Production of high level of cellulase-free and Thermostable xylanase by a wild strain of Thermomyces lanuginosus using beechwood xylan. J. Biotechnol., 30: 283-297, 1993.

13. Hoq, M.M.; Hempel, C.; Deckwer, W. Cellulase-free xylanase by Thermomyces lanuginosus RT9: effect of agitation, aeration and medium components on production. J. Biotechnol., 37: 49-58, 1994.

14. Kadowaki, M.K.; Souza, C.G.M.; Simão, R.C.G.; Peralta, R.M Xylanase Production by Aspergillus tamarii. Appl. Biochem. Biotechnol., 66(3): 97-106, 1997.

15. Kormelink, F.J.M.; Voragen, A.G.J. Degradation of different \{(glucurono) arabino $\}$ xylans by a combination of purified xylandegrading-enzymes. Appl. Microbiol. Biotechnol., 38: 688-695, 1993.

16. Kumar, S.; Tsai, C.; Ma, B.; Nussinov, R. Contribution of salt bridges toward protein thermostability. J. Biomol. Structure \& Dynamics. 11(1): 79-85, 2000.

17. Lowry, O.H.; Rosebrough, N.J.; Farr, A.L.; Randall, R.J. Protein Measurement with the Folin phenol reagent. J. Biol.Chem., 193: 265-275, 1951

18. Miller, G.L. Use of dinitrosalicylic acid reagent for determination of reducing sugars. Anal. Chem., 31: 426-428, 1959.

19. Montgomery, D.C. Design and analysis of experiments, $4^{\text {th }}$ edition, John Wiley \& Sons, New York, 1997, 1004p.

20. Numao, S.; Maurus, R.; Sidhu, G.; Wang, Y.; Overall, C.M.; Brayer, G.D.; Withers, S.G. Probing the role of the chloride ion in the mechanism of human pancreatic $\alpha$-amylase. Biochemistry., 41: 215225, 2002.

21. Purkarthofer, H.; Sinner, M.; Steiner, W. Cellulase-free xylanase from Thermomyces lanuginosus: optimization of production in submerged and solid-state culture. Enz. Microb. Technol., 15: 677682, 1993.

22. Roncero, M.B.; Torres, A.L.; Colom, J.F.; Vidal, T. Effects of xylanase treatment on fibre morphology in totally chlorine free bleaching (TCF) of Eucalyptus pulp. Proc. Biochem., 36: 45-50, 2000

23. Singh, S.; Reddy, P.; Haarhoff, J.; Biely, P.; Janse, B.; Pillay, B., Pillay, D.; Prior, B.A. Relatedness of Thermomices lanuginosus strains producing a thermostable xylanase. J. Biotechnol., 8: 119$128,2000$.

24. Sola-Penna, M.; Meyer-Fernandes, J.R. Stabilization against thermal inactivation promoted by sugars on enzyme structure and function: why is trehalose more effective than other sugars. Arch.Biochem. Bioph., 360(1): 10-14, 1998.

25. Vogt, G.; Woell, S.; Argos, P. Protein thermal stability, hydrogen bonds, and ion pairs. J. Mol. Biol., 269: 631-643, 1997.

26. Wilson, K.; Goulding, K. A biologist's guide to principles and techniniques of practical biochemistry, Arnold, E. London, 1989. 